\title{
Representasi Single Parent dalam Film Susah Sinyal
}

\author{
Muhammad Faisal Wisnu Ananta Putra \\ Universitas Muhammadiyah Surakarta \\ E-mail: putrafaisal127@gmail.com* \\ *corresponding author
}

\section{Keywords:}

representation, stereotype, single parent, semiotics

Kata Kunci:

representasi, stereotip, single parent, semiotika

\begin{abstract}
The Susah Sinyal movie is a film that takes the theme of the life of a single parent woman in carrying out her role. single parent is a picture of a single parent who is very tough because they have to play both roles as father and mother. The purpose of conducting research is to show how the stereotypical representation of single parent women in film Susah Sinyal. This type of research used in this study is a qualitative study using the Roland Barthes semiotic analysis method. This research focuses on the role of a single parent woman named Ellen who is represented in the film. The results of this study indicate that the stereotypical representation of single parent is shown in 3 (three) categories. First, the stereotype representation of single parent women that describes emotional women and women who are weak in carrying out both roles. Second, the representation of women's resistance based on liberal feminism which shows the stereotype that single parent women are hardworking women. Third, the representation of patriarchal ideology found a stereotype that problem children are the failure of single parent women in educating and caring for children.
\end{abstract}

\begin{abstract}
ABSTRAK
Film Susah Sinyal adalah film yang mengangkat tema kehidupan perempuan single parent dalam menjalankan perannya. single parent merupakan gambaran dari orang tua tunggal yang sangat tangguh karena harus memerankan kedua peran yaitu sebagai ayah dan ibu. Adapun tujuan melakukan penelitian yaitu menunjukkan bagaimana representasi stereotip perempuan single parent pada film susah sinyal. Jenis peneltian yang digunakan dalam penelitian ini adalah penelitian kualitatif dengan menggunakan metode analisis semiotik Roland Barthes. Penelitian ini berfokus pada peran perempuan single parent bernama Ellen yang direpresentasikan dalam film. Hasil penelitian ini menunjukkan bahwa reperesentasi stereotip single parent ditunjukkan dalam 3 (tiga) kategori. Pertama, represntasi stereotip perempuan single parent yang menggambarkan perempuan yang emosional dan perempuan yang lemah dalam menjalankan kedua peran. Kedua, representasi perlawanan perempuan berdasarkan feminisme liberal yang menunjukkan stereotip bahwa perempuan single parent adalah perempuan yang pekerja keras. Ketiga, representasi ideologi patriarki menemukan adanya stereotip bahwa anak yang bermasalah merupakan kegagalan perempuan single parent dalam mendidik dan mengasuh anak.
\end{abstract}




\section{PENDAHULUAN}

Film merupakan suatu karya seni untuk memberikan gambaran kepada publik tentang kehidupan sesorang. Film dapat merekam sebuah realitas keadaan suatu tempat dan budaya yang terjadi. Film merupakan bayangan yang diangkat dari suatu kejadian dalam kehidupan sehari-hari yang selalu menimbulkan adanya kecenderungan antara film dengan dunia nyata (Sobur, 2016)

Kebanyakan orang melihat film hanya sebagai sarana hiburan saja. Padahal film juga dapat dijadikan sebagai media komunikasi dalam menyampaikan informasi maupun pesan-pesan yang terkandung dalam kehidupan (McQuail, 2011). Penggambaran yang ditampilkan kedalam film merupakan tanda-tanda untuk menjelaskan peran seseorang yang ditampilkan kedalam film tersebut. Salah satunya film yang mengangkat tema tentang perempuan single parent.

Pada dasarnya, perempuan single parent adalah gambaran dari orang tua tunggal yang sangat tangguh. Tidak hanya beban tanggung jawab perempuan single parent yang harus dipikul, tetapi peremuan single parent harus menjalankan peran ganda, yaitu peran sebagai ayah dan peran sebagai ibu dalam kelangsungan hidup keluarganya (Layliyah, 2013)

Menurut Qaimi perempuan single parent harus menjalankan dua tugas sekaligus, yaitu tugas yang sewajarnya seorang ibu lakukan dalam mengurus rumah tangga dan tugas seorang ayah dalam memimpin keluarga. Selain itu, perempuan single parent akan memiliki dua bentuk sikap, sikap seorang ibu yang lemah lembut dan penuh perhatian terhadap anakya, dan sikap ayah yang tegas dalam memimpin keluarga, serta menjadi panutan dalam menjalankan kehidupan rumah tangga (Qaimi, 2003).

Dalam menjalankan kedua peran tersebut bukanlah suatu hal yang mudah sebagai perempuan single parent. Perempuan single parent akan dituntut untuk bisa memberikan kasih sayang dan kehangatan kepada anaknya, sekaligus harus bisa memenuhi kebutuhan keluarga. Hanya perempuan yang tangguh dan rela menjadi single parent untuk menjadi tulang punggung keluarga. Dari pernyataan tersebut masyarakat melihat adanya stereotip yang terjadi pada perempuan single parent. Perempuan single parent sering dipandang sebagai perempuan yang lemah, emosional dan gagal dalam menghidupi serta mendidik anak beserta keluarga. Oleh karena itu, peneliti mengindikasi adanya stereotip perempuan single parent yang ditampilkan melalui tokoh Ellen dalam film Susah Sinyal.

Ellen direpresentasikan sebagai perempuan single parent yang mandiri, cekatan dan pekerja keras dalam menghidupi keluarganya. Tetapi disisilain perannya sebagai ibu dalam mengasuh dan mendidik anaknya (Kiara) tidak tersampaikan. Kiara merasa kurangnya perhatian dan dukungan seorang ibu yang seharusnya dia dapatkan seperti anak pada umumnya. Dari situlah Kiara tumbuh sebagai gadis pemberontak dan melampiaskan emosi disosial media. Hubungan Kiara dan Ellen yang tidak harmonis menunjukkan kurangnya cinta dan kasih sayang yang diberikan seorang ibu kepada anaknya. Maka dapat dilihat dari adegan/scene inilah bagaimana stereorip seorang perempuan single parent dalam menghidupi, mendidik dan menjaga atau merawat dalam menentukan proses kehidupan anak dan keluarga.

Penelitian sebelumnya terkait dengan perempuan single parent telah dilakuan oleh Lucy Pujasari Supratman (2018) berjudul Family Communication On Single Mother Families. Penelitian ini berfokus pada peran Ibu single parent. Penelitian ini menggunakan metode kualitatif dengan pendekatan studi kasus. Hasil yang ditunjukkan dalam penelitian ini adalah ada dua komunikasi interpersonal pada semua informan, yaitu komunikasi koersif dan demokratis yang terjadi dilingkunagan sosial. Berbeda dengan penelitian sebelumnya, penelitian ini berfokus untuk melihat stereotip single parent yang direpresentasikan didalam media, yaitu film Susah Sinyal. Perbedaan juga terdapat pada metode penelitian ini adalah semiotika Roland Barthes. Sedangkan persamaan dengan penelitian sebelumnya, sama-sama menggunakan single parent sebagai subjek yang diteliti.

Dalam dunia perfilman, film memiliki cara tersendiri untuk merepresenasikan suatu makna yang telah diproduksi dengan tujunan memperlihatkan peran single parent dari suatu film tersebut. single parent selalu terstereotipkan oleh adanya pemikiran masyarakat tertentu yang kemudian harus mengintimidasi perempuan single parent sebagai perempuan yang lemah, emosional dan gagal dalam menghidupi, mendidik dan menjaga anaknya.

Berdasarkan penelitian yang berkaitan dengan representasi stereotip single parent dalam film. Maka dipilihlah metode semiotika untuk melihat bagaimana masyarakat memproduksi makna dan nilai dari sistem komunikasi melalui "tanda" (Vera, 2014). Jika mengkaji latar belakang di atas, maka rumusan masalah yang diajukan dalam penelitian ini yaitu, bagaimana representasi stereotip perempuan single parent yang ditampilkan dalam film Susah Sinyal?.

Penelitian ini diharapkan dapat memberikan kontribusi yang bermanfaat, serta dapat membantu memberikan bukti empiris melalui tanda dan makna mengenai stereotip perempuan single parent yang direpresantasikan menggunakan analisis semiotika. Penelitian ini juga diharapkan memberikan gambaran dan menambah pengetahuan perfilman di Indonesia.

\section{A. Film Sebagai Bentuk Komunikasi Massa}

Film merupakan bentuk dari salah satu media komunikasi massa. Hal ini disebabkan karena bentuk komunikasi ini yang menggunakan saluran berupa media yang biasanya disebut sebagai media massa. Film memiliki fungsi informatif, edukatif dan persuasif. Menurut Bittner (dalam Ardiyanto dkk, 2005) menjelaskan bahwa komunikasi massa adalah pesan 
yang dikomunikasikan menggunakan media massa ke sebagian besar orang. Komunikasi massa juga merupakan produksi dan distribusi yang berbasis teknologi dan insitusional dari aliran suatu pesan yang terus-menerus dibagikan secara luas dalam masyarakat industri (Gerbner dalam Ardiyanto dkk, 2005).

Film selalu bersifat linear, artinya film dapat memberikan pengaruh dan membentuk masyarakat sesuai pesan (message) yang terkandung didalam film tersebut. Menurut Irawanto (1999), menjelaskan bahwa film merupakan sebuah rekaman dari realitas masyarakat yang sudah muncul dan berkembang didalam kehidupan yang kemudian ditayangkan ke atas layar. Jadi, apa yang ditampilan kedalam film merupakan pandangan yang tidak jauh dari kehidupan masyarakat sekitar.

Menurut Turner 1988 (dalam Hutomo, 2016) film memberikan kepuasan dan kenikmatan tersendiri sebagai sarana hiburan dan tontonan yang digambarkan melalui layar. Maka, film dapat memberikan pandangan dan memberikan potensi untuk mempengaruhi yang besar kepada penontonya. Turner juga mengatakan bahwa tayangan film dapat memberikan konstruksi sosial dan budaya yang kemudian bisa diterima sebagai bagian dari kehidupan masyarakat.

Film juga memiliki batasan durasi, mengingat sebuah film akan memiliki tingkat intensitas yang juga ditentukan oleh batasan waktu. Intensitas itu diantaranya adalah adanya kendala penciptaan, yang tentunya mempengaruhi pengaturan tempo, irama, dan penekanan penekanan yang berbeda ketika seseorang membuat film yang memiliki durasi panjang (prakosa, dalam Junaedi \& Arifianto 2016).

Genre yang ditampilkan di dalam film juga bermacam-macam, seperti film laga, komedi, horor, seks, sejarah dan drama. Selain sebagai sarana hiburan, film juga memiliki suatu kepentingan tersendiri dalam memberikan tuntunan serta memberikan nilai-nilai yang bisa dibaca baik secara cermat dan kritis. Film dapat dilihat dari tiga dominan yaitu produksi (bagaimana film tersebut diciptakan atau dibuat), presentasi (bagaimana sebuah film menampilkan realitas yang ada) dan resepsi (bagaimana penonton atau khalayak memberikan tanggapan dan mengambil nilai-nilai yang terkandung didalam film tersebut) (Lukmantoro, 2016).

Menurut Rushton dan Bettinson (dalam Lukmantoro, 2016) mengungkapkan tentang bagaimana film bekerja, bagaimana film mengirimkan makna dan fungsi-fungsi apa saja yang diberikan oleh film tersebut, serta bagaimana film akan mempengaruhi penontonnya. Teori ini berfungsi untuk memberikan bantuan dalam memahami film dengan lebih baik, bahkan untuk menunjukkan bahwa film dapat diuraikan dari aspek yang sesuai dengan kebutuhan dan minat penontonnya. Teori ini juga dapat membaca, membongkar dan mengintrogasi tanda-tanda atau kode-kode yang ditampilkan memalui bahasa, serta direpresentasikan sebagai tontonan.

\section{B. Representasi}

Representasi berasal dari bahasa Inggris (representation) yang diartikan sebagai perwakilan atau penggambaran. Secara singkat representasi bisa diartikan sebagai gambaran yang terjadi dalam kehidupan masyarakat yang diaplikasikan melalui suatu media. Menurut Danesi (2010), representasi didefinisasikan sebagai pengguna tanda dalam menghubungkan, menggambarkan, memotretkan dan memproduksi sesuatu yang bisa dilihat, dibayangkan, dindera atau dirasakan dalam bentuk fisik. Tanda yang dimaksud kata, suara, gambar dan cerita yang bisa diartikan sebagai sebuah ide dan emosi dalam fakta yang telah dimaknai dari pesan yang disampaikan.

Menurut Stuart Hall (1997) representasi diartikan sebagai suatu proses produksi dan pertukaran makna berdasarkan konsep yang ada di luar pikiran dengan menggunakan perantara bahasa. Representasi selalu diproduksi melalui makna bahasa dengan menggunakan dua prinsip, yaitu untuk mengartikan sesuatu dalam menjelaskan dan menggambarkan sebuah imajinasi yang dipikirkan melelui perasaan seseorang. Sedangkan prinsip kedua, representasi dapat dipergunakan untuk menjelaskan kontruksi makna yang tertera didalam simbol. Makna yang diproduksi dalam suatu anggota budaya tertentu yang melibatkan penggunaan bahasa, tanda dan gambar yang bisa mewakili atau mempresentasikan berbagai kategori. Representasi ini juga belum tentu bersifat nyata, melainkan dapat menunjukkan ide abstrak dan fantasi.

Sedangkan menurut Graeme Burton (2007), representasi dalam arti luas mengacu pada penggambaran kelompokkelompok dan institusi sosial. Penggambaran tidak hanya berkenaan dengan tampilan fisik (appearance) dan deskripsi, melainkan juga terkait dengan makna (atau nilai) di balik tampilan fisik. Tampilan fisik representasi adalah sebuah jubah yang menyembunyikan bentuk makna yang sesungguhnya yang ada di baliknya (Burton, 2007). Dalam pandangan Burton, ada beberapa konsep yang perlu dipelajari dalam representasi, antara lain seperti stereotip, identitas, ideologi dan wacana.

Stereotip dapat diartikan sebagai konsepsi yang secara tetap melekat pada kelompok tertentu. Identitas adalah "pemahaman" kita terhadap kelompok yang telah direpresentasikan - sebuah pemahaman tentang siapa mereka, bagaimana mereka dinilai dan dilihat oleh orang lain. Ada juga pemahaman dimana identitas didefinisikan dari sudut yang berlawanan atau beroposisi. Konsep identitas juga berkaitan dengan 'perbedaan' artinya identitas tersebut membuat mereka yang direpresentasikan berbeda dengan yang tidak direpresentasi. Selanjutnya representasi dilihat sebagai ungkapan idiologi artinya representasi mengungkapkan berbagai jenis kekuasaan yang berbeda dengan masyarakat. Kemudian Burton juga menyatakan bahwa representasi memiliki hubungan dengan wacana, karena bahasa yang digunakan didalam media saling berkaitan (Burton, 2007). 


\section{Stereotip dalam Komunikasi Multikultur}

Menurut Abbate, Boca dan Bocchiaro (dalam Semovar dkk, 2010), stereotip dapat diartikan sebagai bentuk yang terkandung kedalam susunan kognitif berupa pengetahuan, kepercayaan dan harapan dari penerima mengenai kelompok sosial tertentu. Proses kognitif merupakan perpanjangan dari kategorisasi yang nantinya membuat struktur melalui peristiwa, objek dan pengalaman. Proses tersebut membutuhkan pengorganisasian dan penyederhanaan dari berbagai fenomena dan kategori yang berlabel. Stereotip merupakan bagian dari sebuah budaya yang sudah turun temurun yang selalu diteruskan dan selalu dipercayai oleh masyarakat tertentu.

Dengan kata lain, stereotip merupakan persepsi atau kepercayaan yang dianut seseorang terhadap individu atau kelompok mengenai pendapat dan sikap yang sudah terbentuk sejak dulu (Semovar dkk, 2010). Stereotip sudah ada sejak dulu dan dikembangkan dari waku ke waktu, dimana orang-orang mempunyai persepsi sendiri untuk menilai seseorang atau kelompok tersebut.

Maka dari itu, stereotip adalah konsepsi yang sudah ditetapkan dan sudah melekat pada suatu kelompok tertentu. Jadi, apa bila kita ingin mengetaui stereotip seseorang, hal yang harus dilakukan adalah mengidentifikasi orang tersebut termasuk apakah termasuk bagian dari anggota kelompok tertertentu, kemudian baru memberikan penilaian terhadap orang tersebut dengan cara melihat latar belakangnya. Stereotip juga dapat terjadi ababila seseorang cenderung melakukan kategorisasi. Kategorisasi tersebut dapat terbentuk pada anggota kelompok yang mendapat atribusi dari sebuah anggota kelompok yang lain. Atribusi yang diberikan dapat bersifat positif maupun negatif (Sukmono \& Junaedi, 2014).

Persepsi positif ini tidak akan menimbulkan persoalan atau konflik, melinkan sebaliknya persepsi negatif akan menimbulkan permasalahan sehingga dapat mengakibatkan adanya sebuah konflik tertentu. Apa yang ditampilkan oleh media akan menimbulkan sudut pandang yang signifikan, karena media selalu memberikan gambaran mengenai stereotip tertentu yang bersifat positif atau negatif, meskipun apa yang ditampilkan belum tentu akan kebenarannya (Wood dalam Semovar dkk, 2010).

Maka dari itu apa yang selalu ditampilkan di dalam kehidupan seseorang selalu menimbulkan stereotip yang nantinya berpengaruh dalam masyarakat. Masyarakat selalu melihat stereotip dari suatu proses dalam mengkategorikan orang atau objek kedalam kategori tersebut, atau penilaian terhadap seseorang atau objek berdasarkan kategori tersebut (Mulyana, 2005).

Dalam hal ini, masyarakat seringkali menilai seseorang bukan dari penilaiannya sendiri, melainan dari penilaian yang didapat oleh orang lain, misalnya saja bila mendengar kata perempuan single parent, seseorang langsung beranggapan bahwa perempuan single parent dipandang sebagai perempuan yang lemah, emosional dan gagal yang jelas-jelas merupakan stereotip negati. Sedangkan stereotip positif, seperti asumsi bahwa perempuan single parent adalah perempuan yang bekerja keras dalam menghidupi keluarganya. Meskipun pada kenyataanya perempuan single parent tidak semua seperti itu.

\section{Teori Semiotika Roland Barthes}

Menurut Saussure, bahasa adalah sebuah sistem tanda (sign) yang tersusun atas dua bagian, yaitu penanda (signifier) dan pertanda (signified). Tanda merupakan kesatuan dari kesuruhan suatu bentuk penanda (signifier) dari sebuah ide atau pertanda (signified). Penanda (signifier) diartikan sebagai bentuk atau wujud fisik yang diambil oleh suatu tanda, seperti bunyi, gambar, huruf, visual dan sebagainya, sedangkan pertanda (signified) merupakan konsep dan makna dari apa yang ditandai. Hubungan antar keduanya (signifier dan signified) disebut sebagai "signifikasi” yang menghubungkan antara bunyi dan bentuk bahasa atau penanda dangan makna atau pertanda yang bersifat arbiter, artinya sifat itu tidak ada hubungan alamiah antara bentuk (penanda) dan makna (pertanda), serta terikat pada struktur (Junaedi,2019).

Dalam teorinya, Saussure juga membedakan bahasa (langue) dengan perkataan (parole). Langue diartikan sebagai abstraksi dan artikulasi bahasa pada tingkat sosial budaya, maksudnya sistem formal yang bisa dianalisis secara terpisah dari penggunaan dalam kehidupan sehari-hari. Sedangkan parole merupakan ekspresi bahasa pada tingkat individu, dengan kata lain penggunaan bahasa dalam mengutarakan maksud. Maka parole selalu terikat dengan langue, karena hubungan antar keduanya sangatlah berpengaruh pada perubahan sifat bahasa yang sangat dinamis (Junaedi, 2019).

Dalam pandangan Saussure, Barthes juga mempercayai bahwa hubungan antara signifier dan signified tidak dapat terbentuk secara alamiah, melainkan harus bersifat arbiter. Kemudian Roland Barthes mengembangkan konsep semiologi Saussure dengan memaknai dua tatanan penandaan (two order of signification), yaitu primary signification atau denotasi yang terdiri atas penanda dan pertanda yang dapat menghasilkan makna yang eksplisit, langsung dan nyata, serta mudah dikenali secara langsung oleh panca indra (makna sebenarnya sesuai kamus). Sedangkan secondary signification atau konotasi merupakan tanda yang penandanya mempunyai keterbukaan makna, makna yang dimaksud makna implisit, tidak langsung dan tidak pasti, artinya ada kemungkinan penafsiran-penafsiaran baru (makna ganda yang lahir dari pengalaman kultur dan personal) (Junaedi, 2019).

Menurut Barthes (dalam Barker, 2000), tatanan kedua (konotasi) selalu diidentikkan dengan adanya operasi ideologi, yang disebut dengan istilah mitos. Jadi, mitos merupakan bentuk untuk mengungkapakan dan memberikan 
pembenaran terhadap nilai-nilai dominan dan berlaku dalam periode tertentu. Barthes mengartikan mitos sebagai bahasa, maka mitos merupakan sebuah sistem komunikasi dan sebuah pesan.

\section{METODE PENELITIAN}

Jenis peneltian yang digunakan dalam penelitian ini adalah penelitian kualitatif dengan menggunakan metode analisis semiotik Roland Barthes. Agar bisa melihat tanda-tanda di dalam representasi, maka memerluakan studi semiotika untuk membacanya. Penelitian ini berfokus pada peran ibu single parent (Ellen) yang direpresentasikan dalam film Susah Sinyal. Ellen yang didasarkan pada seorang ibu dari karakter anaknya (Kiara) yang merefleksikan sebagian perempuan single parent yang berkaitan dengan bagaimana peran, tugas dan kedudukan dalam mengasuh dan mengurus anaknya.

Dalam penelitian ini, peneliti menggunakan teknik purposive sampling. Teknik ini biasanya digunakan untuk memperoleh data-data yang lebih mendalam dari teknik yang sudah tercakup dalam sebuah kriteria-kriteria tertentu (Kriyantono, 2010). Melalui teknik ini, berfokus pada scene, yaitu dengan mengambil beberapa adegan yang ada dalam scene untuk melihat kategori-kategori stereotip di dalam film Susah Sinyal, kemudian akan dijadikan sempel sesuai penggambaran perempuan single parent.

Teknik pengumpulan data pada penelitian ini menggunakan data primer dan sekunder. Data primer dalam penelitian ini berupa tanda-tanda yang diperoleh melalui dokumentasi. Teknik ini digunakan untuk menggali data-data baik secara sistematis dan objektif, hal tersebut agar dapat mendapatkan informasi yang dapat mendukung analisis dengan interpretasi data (Kriyantono, 2010). Dokumentasi dalam penelitian ini dengan cara melihat film Susah Sinyal yang telah dirilis pada bulan Desember 2017 dengan durasi 1jam 50menit. Sedangkan data sekunder berupa referensi dari buku, jurnal, artikel dan website yang diperlukan dalam penelitian ini.

Tahapan analisis data yang dilakukan dalam peneltian ini, yaitu dengan menonton film Susah Sinyal dengan memotong setiap scene-scene yang berkaitan dengan stereotip perempuan single parent. Kemudian dianalisis dengan teori yang dikemukakan oleh Roland Barthes sesuai yang sudah dijelaskan dalam teori sebelumnya, sehingga bisa mendapatkan data-data yang valid.

Teknik validitas dalam penelitian ini dengan menggunakan analisis trianggulasi. Teknik trianggulasi teori digunakan untuk memanfaatkan dua atau lebih teori utama dengan alasan pengajian data apakah sudah valid dan menginterprestasi suatu data agar dapat menjadi data yang komprehensif (Kriyantono, 2010). Teknik ini digunakan untuk mengetahui kebenaran melalui data empiris dan digunakan sebagai kelengkapan yang bertujuan mengetahui stereotip single parent dalam film susah sinyal.

\section{HASIL DAN PEMBAHASAN}

Berdasarkan hasil analisis data dalam penelitian ini menunjukkan representasi stereotip single parent melalui film Susah Sinyal. Hasil penelitian ini dianalisis dalam bentuk korpus, yang berupa tanda verbal dan non verbal yang berupa potongan-potongan scene atau adegan yang merepresentasikan single parent. Peneliti menemukan beberapa kategorikategori yang merepresentasikan stereotip single parent dalam film ini, diantaranya representasi stereotip perempuan single parent, representasi perlawanan perempuan berdasarkan feminisme liberal dan representasi ideologi patriarki dalam film Susah Sinyal.

\section{A. Representasi Stereotip Perempuan Single Parent}

Stereotip secara umum dapat diartikan sebagai pelabelan atau penandaan terhadap sesuatu kelompok tertentu. Pada dasarnya stereotip dapat menimbulkan kerugian dan diskriminasi. Salah satunya stereotip yang bersumber dari pandangan gender (Fakih, 2011). Banyak sekali ketidakadilan terhadap jenis kelamim, terutama yang terjadi pada perempuan. Masyarakat manapun masih memegang stereotip bahwa kaum perempuan selalu dikaitkan dengan sifat yang emosional dan lemah, sedangkan laki-laki bersifat rasional dan kuat (Mapstone, dalam Wood 2009).

Dalam film Susah Sinyal, stereotip perempuan single parent yang ditunjukkan dalam film ini dapat dikategorikan menjadi dua, yaitu perempuan single parent yang memiliki sifat emosional dan perempuan single parent yang lemah dalam menjalankan kedua perannya. 
Tabel 3.1. Penggambaran stereotip perempuan single parent yang emosional

\begin{tabular}{|c|c|}
\hline Dialog/suara & Visual \\
\hline $\begin{array}{l}\text { Iwan : Ribet ya, pantesan loe males kawin lagi } \\
\text { Ellen : Bukan karena itu juga ya } \\
\text { Iwan : Karena apa? } \\
\text { Ellen : Karena semua laki-laki itu brengsek } \\
\text { Iwan : Termasuk aji } \\
\text { Ellen : Yaa gue gak taulah } \\
\text { Iwan : Nah loh lo gak taukan, siapa tau dia baik }\end{array}$ & $\begin{array}{l}\text { Gambar 3.1: Ellen dan Iwan sedang berbicara ditempat } \\
\text { makan } \\
\text { Connotative Signifier } \\
\begin{array}{l}\text { Ellen merasa tersindir atas perkataan yang di bicarakan oleh } \\
\text { Iwan. }\end{array}\end{array}$ \\
\hline \multicolumn{2}{|c|}{ Connotative Signified } \\
\hline $\begin{array}{l}\text { Sikap yang dilakukan Ellen merupakan bentuk kekesalan atas } \\
\text { umumnya, laki-laki ditempatkan pada posisi kiri (aktif, rasior } \\
\text { (pasif, emosional) (Hartanto, 2007). Perempuan single parent } \\
\text { mudah marah apabila membahas soal pernikahan. Perempuan } \\
\text { berhasilan dalam rumah tangga menimbulkan trauma yang cu } \\
\text { antar pasangan membuat meraka harus berpisah dan memilih } \\
\text { suami dengan istri yang memutuskan mereka untuk hidup terp } \\
\text { keluarga dapat berupa kekerasan fisik ataupun psikis. }\end{array}$ & $\begin{array}{l}\text { kataan Iwan yang ditujukan kepada dirinya. Pada } \\
\text { sementara perempuan ditempatkan pada posisi kanan } \\
\text { rupkan perempuan emosional yang mudah tersindir dan } \\
\text { gle parent merasa pernah gagal dalam berkeluarga. Ketidak } \\
\text { dalam bagi seseorang, karena adanya konflik yang terjadi } \\
\text { ajadi seorang single parent. Ketidak harmonisan antara } \\
\text { h. Faktor utama yang menimbulkan ketidak harmonisan }\end{array}$ \\
\hline
\end{tabular}

Mitosnya adalah Ellen sebagai perempuan single parent memiliki sifat emosional. Selain itu, seorang perempuan akan lebih mudah mengekpresikan emosi yang sedang dirasakan. Tak jarang bahwa seorang perempuan sering dinggap sebagai individu yang baper-an (bawa perasaan). Seperti yang digambarkan pada potongan gambar adegan 3.1 menggambarkan sebagai seorang perempuan yang mudah tersinggung atau sensitif.

Selain sifat emosional yang digambarkan pada scene berikut, stereotip perempuan single parent juga digambarkan sebagai perempuan yang lemah dalam menjalankan kedua peran, yaitu peran ayah dan peran ibu, seperti yang di representasikan pada scene dibawah ini. 
Tabel 3.2. Penggambaran stereotip perempuan single parent yang lemah

\begin{tabular}{|c|c|}
\hline Dialog/suara & Visual \\
\hline Suara backsound musik & Gambar 3.2: Saodah (seorang pembantu) mempekerjakan \\
\hline Signifier dan Signified Denotative & Connotative Signifier \\
\hline $\begin{array}{l}\text { Seorang perempuan yang memakai kaos polos, celana } \\
\text { panjang polos dan sedang memegang benda panjang, } \\
\text { serta benda berbentuk tabung yang berisikan air, } \\
\text { menandakan bahwa orang tersebut sedang mengerjakan } \\
\text { pekerjaan rumah yaitu mengepel. Seseorang yang } \\
\text { membantu melakukan pekerjaan rumah tangga biasanya } \\
\text { disebut dengan pembantu. } \\
\text { Pengambilan gambar dengan Long Shot untuk } \\
\text { memperlihatkan apa yang sedang dia kerjakan dan untuk } \\
\text { menunjukkan latar belakangnya. }\end{array}$ & $\begin{array}{l}\text { Saodah (seorang pembantu) merupakan orang suruhan dari } \\
\text { Ellen untuk membantu mengerjakan pekerjaan dalam ranah } \\
\text { domestik. Dalam ranah domestik, pakaian yang dikenakan tidak } \\
\text { begitu dipermasalahkan. }\end{array}$ \\
\hline \multicolumn{2}{|c|}{ Connotative Signified } \\
\hline $\begin{array}{l}\text { Perempuan single parent merupakan perempuan yang lem } \\
\text { ranah publik dan peran ibu dalam ranah domestik. Maka, } \\
\text { bagi perempuan single parent. Karena seorang pembantu } \\
\text { dalam menjalankan kedua perannya. Seorang pembantu di } \\
\text { satunya yang berkaitan dengan urusan pekerjaan rumah ta } \\
\text { seperti menyapu, mengepel, mencuci, dan lain-lain (Raha) }\end{array}$ & $\begin{array}{l}\text { dalam menjalankan kedua peran, antara peran ayah dalam } \\
\text { mperkerjakan seorang pembantu merupakan solusi yang tepat } \\
\text { at meringankan beban yang dipikul perempuan single parent } \\
\text { ih agar dapat membantu mengerjakan pekerjaan domestik, salah } \\
\text { ga seperti memasak, menyiapkan makan, membersihkan rumah } \\
\text { 2017). }\end{array}$ \\
\hline
\end{tabular}

Mitos yang terkandung adalah perempuan single parent merupakan perempuan yang lemah tidak bisa hidup sendiri dan memerankan kedua peran tersebut secara bersamaan. Kebanyakan perempuan single parent memilih pekerjaan publik yaitu bekerja, dibandingkan pekerjaan domestik. Tetapi hanya perempuan single parent yang sukses (menengah keatas) yang bisa memperkerjakan seorang pembantu. Mungkin berbeda jika perempuan single parent tersebut berada dikelas sosial menengah kebawah, karena perempuan single parent dituntut untuk bisa memerankan kedua peran tersebut secara bersamaan tanpa bantuan orang lain (Rahayu, 2017).

Representasi stereotip perempuan single parent menunjukkan perempuan single parent merupakan perempuan yang sensitif dan mudah marah apabila dirinya merasa tersindir dengan perkataan yang menurutnya menyakitinya, seperti yang digambarkan dalam potongan gambar adegan 3.1. Sedangkan dalam potngan gambar adegan 3.2 menunjukkan bahwa pada saat perempuan single parent bekerja, tugas domestik biasanya dipindahkan atau dibebankan pada pekerja rumah tangga (PTR). Hal tersebut membuktikan bahwa perempuan single parent tidak mampu menjalankan kedua peran tersebut secara bersamaan, sehingga masyarakat selalu berenggapan bahwa perempuan single parent adalah perempuan yang lemah. Pergeseran peran perempuan single parent juga untuk terhindar dari proses kemiskinan di keluarganya, dan membuktikan bahwa seorang perempuan tidak harus terus menerus berada dalam ranah domestik, sewaktu-waktu seorang perempuan juga bisa ada dalam ranah publik. Setiap orang terutama perempuan memiliki pilihan sendiri agar dirinya bisa terbebas dan mendapatkan kesempatan sesuai apa yang diharapkan. Representasi stereotip perempuan single parent dalam film ini juga tidak terlepas dari oposisi biner, antara single parent dan keluarga lengkap (familly). Seorang single parent selalu ditempatkan pada posisi yang negatif dan tak berdaya, dimana seorang single parent sering dipandang dan dijadikan sebagai sumber permasalahan, serta dituntut untuk bisa menjalankan kedua peran, yakni peran ayah dan peran ibu secara bersamaan. Sedangkan keluarga lengkap (family) berada pada posisi positif dan berdaya, karena dalam keluarga yang utuh biasanya tidak memiliki masalah dan bisa menjalankan kedua peran secara besamaan dengan cara membagi peran tersebut. 


\section{B. Representasi Perlawanan Perempuan berdasarkan Feminisme Liberal}

Perjuangan perempuan di Indonesia selama ini tidak terlepas dari isu-isu gerakan perlawanan perempuan. Gerakan perempuan atau sering dikenal sebagai feminisme merupakan bentuk perlawanan untuk terhindar dari segala sesuatu yang dimarginalisasikan, disubordinasikan, dan direndahkan oleh kebudayaan yang dominan. Baik dalam tataran politik, ekonomi, maupun kehidupan sosial lainnya (Akmala, 2007). Kaum perempuan merasa dirugikan dalam semua bidang dan merasa dinomor duakan dari kaum laki-laki. Dalam faminisme liberal, pandangan bahwa kebebasan dan kesamaan selalu berakar pada rasionalitas, serta adanya pemisahan antara dunia privat dan publik (Muslikhati, 2004). Pada dasarnya feminisme liberal menekankan pada kesetaraan dan kesamaan antara perempuan dengan laki-laki tidak ada perbedaan terutama dalam dunia publik.

Dalam film Susah Sinyal, representasi perlawanan perempuan berdasarkan feminisme liberal ditunjukkan oleh perempuan single parent bernama Ellen, dengan menemukan dua kategori yaitu perempuan dalam kepemimpinan dan perempuan yang intelektual.

Tabel 3.3 . Penggambaran perempuan dalam kepemimpinan

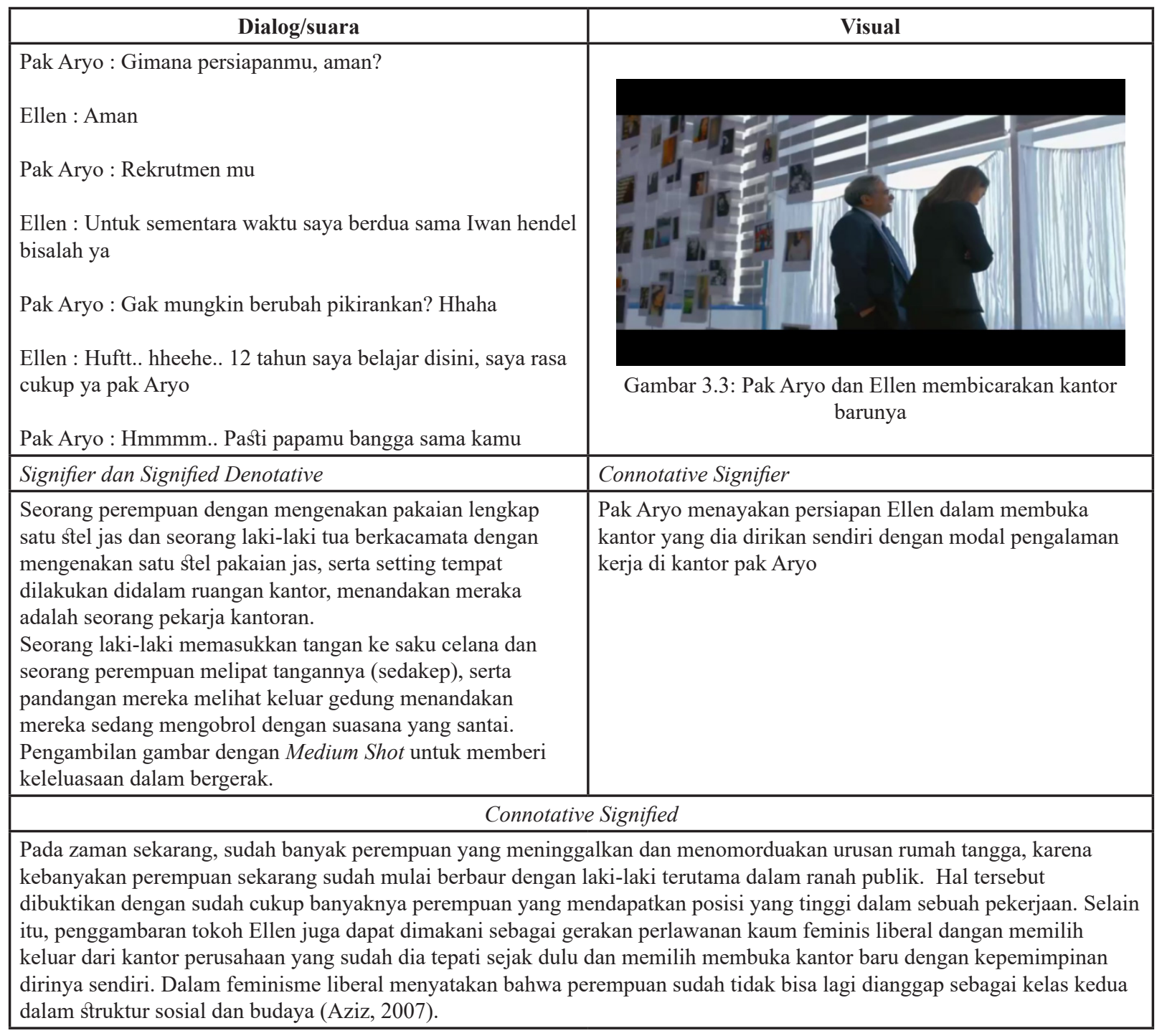

Dari pernyataan diatas juga bisa menjawab mitos, tentang anggapan bahwa perempuan yang hanya bisa diam dirumah dengan mengerjakan pekerjaan rumah, dan mengurus anak, serta hanya mengandalkan suaminya bekerja. Namun, anggapan masyarakat tidak berlaku lagi di jaman modern sekarang ini. Apabila dilihat dari aspek pendidikan, prestasi perempuan dalam mengejar ketertinggalan dari seorang laki-laki justru lebih mengesankan. Jika dulunya lapangan pekerjaan didonminasi oleh laki-laki karena dianggap lebih produktif dibandingkan perempuan, namun saat ini jam kerja perempuan dan laki-laki secara global tidak menurunjukkan perbedaan yang signifikan dan bisa dibilang sama atau setara (Fakih, 2011). 
Sedangkan perlawannan perempuan berdasarkan faminisme liberal juga digambarkan Ellen melalui keberhasilannya memenangkan persidangan dari salah satu klientnya, hal itu ditunjukkan dalam scene berikut :

Tabel 3.4. Penggambaran perempuan yang intelektual

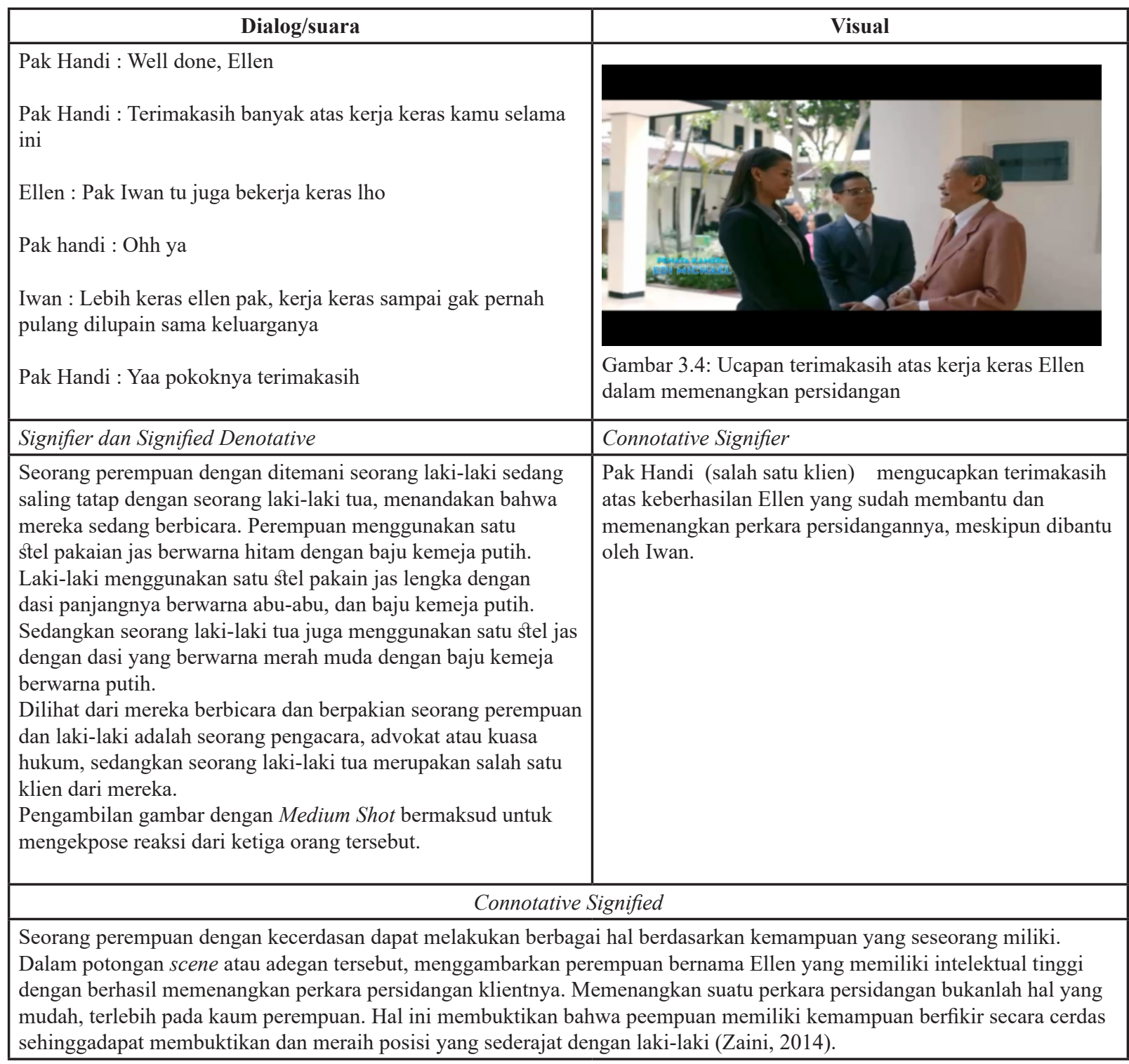

Hal ini justru bisa menjawab mitos yang menyatakan bahwa peran sebagai janda (single mother) dianggap lebih sulit dalam mencari nafkah dibandingkan peran sebagai duda (single father). Dapat dilihat dari penggambaran diatas menunjukkan bahwa dengan kecerdasan yang dimilikinya, perempuan single parent dapat memenuhi kebutuhan keluarganya. Maka dari itu, perempuan sudah tidak bisa dinggap lemah dalam bersaing dengan laki-laki diranah publik. Pada kenyataannya kaum feminis liberal telah berhasil menuntut kesempatan dan peluang perempuan, serta membuktikan kepada kaum laki-laki bahwa dengan adanya dorongan perempuan dalam melawan ketidakadilan (Aziz, 2007).

Representasi perlawanan perempuan berdasarkan feminisme liberal dalam film Susah Sinyal pada potongan scene diatas menunjukan adanya stereotip perempuan single parent yang bersifat positif. Seperti yang dijelaskan oleh Sukmono dan Junaedi (2014) bahwa stereotip dapat bersifat positif dan negatif. Kedua potongan scene diatas mengasumsikan bahwa perempuan single parent adalah perempuan yang pekerja keras. Perempuan yang menjadi single parent bekerja bukan merupakan hal yang baru dalam masyarakat. Perkembangan jaman dan gerakan perempuan yang membuat tidak adanya batasan bagi seorang perempuan untuk bekerja. Dengan menunjukkan kesetaraan antara laki-laki dan perempuan menjadikan paradigma, bahwa laki-laki dan perempuan memiliki kesetaraan dan kesamaan, sehingga tidak ada rasa superioritas bagi kaum laki-laki (Zaini, 2014). Setelah ditinggalkan oleh mantan suami, perempuan single parent masih memiliki kesempatan untuk bangkit dari keterpurukan. Perempuan single parent juga berhak memiliki kesempatan untuk menjadi pemimpin karena tidak semua kaum perempuan harus berada di bawah laki-laki. Perempuan memiliki kesempatan 
yang sama dengan laki-laki untuk sukses diranah publik. Dalam mencapai kesuksesan perempuan juga harus mempunyai kemampuan berpikir secara cerdas agar bisa meraih posisi yang sederajat dengan laki-laki yang tidak semestinya selalu tertindas.

\section{Representasi Ideologi Patriarki dalam Film Susah Sinyal}

Ideologi patriarki merupakan varian dari ideologi hegemoni. Hegemoni pada awalnya dikonsepkan oleh Antonio Gramsci sebagai kekuasaan dan supermasi suatu kelas sosial yang dicapai melalui kepemimpinan intelektual dan moral serta mendapat persetujuan dari kelompok yang dihegemoni (Patria dan Arief, dalam Ratna 2010). Jadi, kaum laki-laki menindas kaum perempuan tidak lagi secara fisik melainkan dari pengaruh ideologi. Ideologi yang masih sering terjadi adalah patriarki. Patriarki dapat diartikan sebagai kekuasaan atau kepemimpinan laki-laki, dengan kata lain "keluarga yang dikuasai oleh laki-laki” (Bhasin dalam Adipoetra, 2016). Patriaki tidak hanya terjadi dalam ranah publik, melainkan juga terjadi dalam ranah domestik. Bentuk patriarki dalam ranah domestik pada dasarnya menjadikan arena produksi rumah tangga dan keluarga sebagai arena utama penindaan terhadap kaum perempuan. Sedangkan patriarki dalam ranah publik, pada dasarnya merupakan bentuk praktik penguasaan oleh ideologi patriarki arena publik, seperti pekerjaan dan negara (Walby, dalam Utami 2018).

Dalam film Susah Sinyal, representasi ideologi patriarki dalam film ditunjukkan oleh perempuan single parent bernama Ellen dengan anaknya bernama Kiara, seperti yang terdapat pada potongan scene berikut :

Tabel 3.5. Penggambaran ideologi patriarki dalam film susah sinyal

\begin{tabular}{|c|c|}
\hline Dialog/suara & Visual \\
\hline $\begin{array}{l}\text { Kepala Sekolah : Kiara pertama-tama sesuai aturan sekolah } \\
\text { kamu dikenakan pengurangan nilai. } \\
\text { Ellen : Bu saya minta maaf atas perbuatan kiara }\end{array}$ & Gambar 3.5: Kiara dan Ellen menghadap guru BP \\
\hline Signifier dan Signified Denotative & Connotative Signifier \\
\hline $\begin{array}{l}\text { Seorang anak perempuan yang memakai pakaian sekolah, } \\
\text { tangan ditekuk diatas meja menandakan bahwa dia seorang } \\
\text { murit. Dengan ditemani oleh seorang ibu disampingnya dan } \\
\text { masih memakai pakaian rapi seperti orang kantoran, dengan } \\
\text { menekuk kedua tangannya di perut menandakan perempuan } \\
\text { tersebut sudah pasrah, hal tersebut juga bisa dilihat dari cara } \\
\text { duduknya. Dilihat dari percakapan mereka, bahwa guru } \\
\text { kepala sekolah sedang memberikan nasihat dan sansi kepada } \\
\text { sang anak. } \\
\text { Pengmbilan gambar dengan Medium Shot untuk } \\
\text { memperlihatkan bahasa tubuh dan suasana yang didalam } \\
\text { kantor. }\end{array}$ & $\begin{array}{l}\text { Ellen diminta datang kesekolah untuk memenuhi panggilan } \\
\text { dan menghadap kepala sekolah demi menyelesaikan } \\
\text { masalah sang anak (Kiara) di sekolah. }\end{array}$ \\
\hline \multicolumn{2}{|c|}{ Connotative Signified } \\
\hline $\begin{array}{l}\text { Kedatangan Ellen ke sekolah merupakan bentuk pertanggung } \\
\text { dan perilaku yang dilakukan Kiara di sekolah merupakan ben } \\
\text { karena kurangnya komunikasi dan kurangnya kasih sayang se } \\
\text { anak akan tumbuh dewasa menjadi seorang pemberontak atau } \\
\text { lingkungan yang sering memojokkan anak karena ibunya ber } \\
\text { akan berpengaruh terhadap perkembangan anak (Wirawan, } 20\end{array}$ & $\begin{array}{l}\text { aban seorang ibu dalam mengasuh anak. Sedangkan sikap } \\
\text { pelampiasan atas kekesalan yang ditujukan kepada ibunya, } \\
\text { perhatian yang diberikan seorang ibu, dianggap membuat } \\
\text { masalah. Belum lagi jika ada anggapan-angapan dari } \\
\text { s sebagai perempuan single parent, hal tersebut bisa jadi } \\
\text {. }\end{array}$ \\
\hline
\end{tabular}

Maka mitos yang muncul adalah ideologi patriarki yang berkembang dimasyarakat terhadap kaum perempuan dalam ranah domestik masih sulit dihilangkan. Masyarakat akan beranggapan tentang patriarki yang ada, dimana seorang anak yang bermasalah dan tidak menuruti perkataan orang tua merupakan bagian kesalahan dari seorang ibu, bukan kesalahan dari seorang ayah. Karena dalam patriarki kaum perempuan ditugaskan untuk mengasuh dan mendidik anak, bukan malah meninggalkannya. Sebagian besar perempuan single parent memilih peran sebagai ayah dalam bekerja, agar bisa menafkahi dan memenuhi kebutuhan keluarga, maka perempuan single parent sering meninggalkan peran seorang 
ibu dalam mengasuh dan mendidik anaknya, sehingga anak itu tumbuh dewasa tanpa kasih sayang dan didikan dari orang tuanya. Dari kejadian tersebut maka seorang ibu akan dinilai gagal menjadi ibu yang baik, mengingat keberhasilan seorang ibu hanya diukur dari keberhasilan dalam ranah domestik.

Kemudian banyak masyarakat yang berasumsi, seorang anak yang dibesarkan oleh orang tua tunggal dengan kurangnya perhatian dan kasih sayang orang tua, sebagian besar akan menjadi anak yang bermasalah. Hal tersebut merupakan stereotip yang sering diterima oleh seorang single parent, karena dianggap gagal dalam mendidik dan mengasuh anak yang mengakibatkan seorang anak tersebut menjadi pemberontak. Stereotip dapat dibangun dari waktu ke waktu, karena interpretasi kelompok masyarakat berbeda-beda berdasarkan lingkungan budaya masing-masing (Sabatini, 2013).

Representasi ideologi patriarki yang terlihat dalam film ini adalah perempuan single parent masih terikat pada ideologi patriarki, dimana kaum perempuan berada dalam kekusaan laki-laki yang menetapkan bahwa mengasuh anak merupakan pekerjaan perempuan dalam ranah domestik. Menjadi perempuan single parent dituntut untuk bisa memerankan kedua perant secara bersamaan (Qaimi, 2003). Kebanyakan perempuan single parent memilih peran ayah dalam ranah publik agar bisa menafkahi dan memenuhi kebutuhan keluarga, agar dapat menyekolahkan anaknya. Namun disisi lain, perempuan single parent akan dianggap gagal menjalankan peran sebagai ibu dalam mendidik dan mengasuh anak. Stereotip yang melekat pada perempuan single parent justru akan terus berkembang dan sulit dihilangkan, serta masyarakat akan trus beranggapan bahwa perempuan single parent adalah perempuan yang gagal. Representasi ideologi patriarki dalam film juga tidak terlepas dari oposisi biner, dimana seorang perempuan dikodratkan berada dalam ranah domestik, seperti mengurus pekerjaan rumah dan mengasuh anak. Sedangkan laki-laki diposisikan dalam ranah publik, seperti bekerja diluar untuk menafkahi keluarga.

\section{PENUTUP}

Hasil yang ditemukan peneliti dari penelitian ini bahwa stereotip single parent dalam film Susah Sinyal direpresentasi melalui 3 (tiga) kategori bentuk makna, yaitu representasi stereotip perempuan singe parent, representasi perlawanan perempuan berdasarkan feminisme liberal, dan representasi ideologi patriarki dalam film. Representasi stereotip perempuan singe parent menunjukkan bahwa perempuan single parent memiliki sifat yang emosional. Perempuan single parent mudah tersindir dan mudah marah karena diaggap memiliki pengalaman yang pahit dalam hidupnya. Serta perempuan single parent selalu dipandang sebagai perempuan yang lemah tidak mampu menjalankan kedua peran, yaitu peran ayah dan peran sebagai ibu, maka menjadi perempuan single parent dituntut untuk bisa memilih salah satu peran tersebut. kebanyakan perempuan single parent memilih menjalankan pekerjaan publik dan meminta orang lain (pembantu) untuk menjalankan pekerjaan domestik.

Representasi perlawanan perempuan berdasarkan feminisme liberal menunjukkan adanya stereotip perempan single parent yang sifatnya positif dengan menemukan asumsi bahwa perempuan single parent adalah perempuan yang pekerja keras. Hal tersebut dapat dilihat dari gerakan perlawanan yang dilakukan perempuan untuk dapat menjadi pemimpin dengan modal intelektual yang dimiliki, serta untuk membuktikan bahwa perempuan juga berhak memiliki kesetaraan yang sama dengan laki-laki dalam ranah publik. Sedangkan representasi ideologi patriarki yang terlihat dalam film ini adalah perempuan single parent masih terikat pada ideologi patriarki, dimana kaum perempuan berada dalam kekusaan laki-laki yang menetapkan bahwa mengasuh anak merupakan pekerjaan perempuan dalam ranah domestik. Seorang ibu dianggap gagal apabila dirinya tidak berhasil menyelesaikan salah satu pekerjaannya sebagai ibu yaitu mengasuh dan mendidik anak. Dalam representasi film tersebut membuktikan masih adanya asumsi terkait stereotip perempuan single parent, dimana seorang anak yang dibesarkan oleh orang tua tunggal sebagian besar akan menjadi anak yang bermasalah, karena kurangnya perhatian dan kasih sayang yang diberikan orang tua, serta seorang ibu akan dikatakan gagal karena mengasuh dan mendidik anak merupakan kodrat dari seorang ibu.

\section{DAFTAR PUSTAKA}

Adipoetra, F.G. (2016). Representasi Patriarki dalam Film Batas. Jurnal E-Komunikasi. Vol 4. No.1.

Akmala, Nisa. (2017). Konstruksi Citra Feminisme Beyonce dalam Lirik Lagu IF I Ware A Boy, Run The World, Flawles. Komunikator. Vol 9 No 2, Desember

Ardianto, E., Komala, L., \& Karlinh, S. (2005). Kommunikasi Massa Suatu Pengantar. Bandung: Simbiosa Rekatama Media.

Aziz, Asmaeny. Feminisme Profetik. Yogyakarta: Kreasi Wacana, 2007.

Barker, Chris. (2000). Cultural Stuudies. Yogyakarta: Kreasi Wacana

Burton, G. (2007). Membincangkan Televisi: Sebuah Pengantar Kepada Studi Televisi. Yogyakarta: Jalasutra.

Danesi, M. (2010). Pesan, Tanda, dan Makna. Yogyakarta: Jalasutra. 
Dwiyani. (2009). Jika Aku harus Mengasuh Anakku sendiri. Jakarta: PT.Alexmedia Copitindo.

Effendy, Heru. (2009). Mari Membuat Film. Jakarta: KGP (Kepustakaan Populer Gramedia)

Fakih, Mansour. (2011). Analisis Gender dan Transformasi Soial. Yogyakarta: Pustaka Perajar.

Hall, S. (1997). Representation: Cultural Representation and Signifying Practices. London: Sage Publication.

Hartanto, D.D. (2007). Representasi stereotype perempuan dalam iklan layanan masyarakat "Sahabat Peduli Anti Kekerasan dalam Rumah Tangga". Nirmana, Vol. 9, No. 2, Juli

Hidayar, A.R.,Anoegrajekti, N., \& Mariati, S. (2003). Representasi Perempuan dalam Novel Supernova-Petir Karya Dewi Lestari. Kajian Feminisme Eksistensialis.

Hutomo, S.B.H. (2016). Membaca Film dalam Junaedi, Fajar [ed] (2016). Menikmati Budaya Layar, Membaca Film. Yogyakarta: UMY, ASPIKOM, Buku Litera.

Irawanto, Budi. (1999). Film, Ideologi, dan Militer Hegemoni Militer dalam sinema Indonesia. Yogyakarta: Media Pressindo.

Junaedi, Fajar. (2019). Semiotika: Sebuah Pengantar Ringkas. Repository UMY

Junaedi, Fajar.,Arifianto, Budi.D. (2016). Dari Analog Menuju Digital: Produksi Film Indie Di Yogyakarta Pasca 1998 dalam Junaedi, Fajar [ed] (2016). Menikmati Budaya Layar, Membaca Film. Yogyakarta: UMY, ASPIKOM, Buku Litera.

Kriyantono, R. (2010). Teknik Praktis Riset Komunikasi. Jakarta: Kencana Prenanda Media Group.

Littlejohn, Stephen W., \& Foss, Karen A. (2009). Encyclopedia of Communication Theory. London: Sage Publication.

Lukmantoro, Triyono (2016). Teori-Teori Film: Sekedar Pengantar Awal dalam Junaedi, Fajar [ed] (2016). Menikmati Budaya Layar, Membaca Film. Yogyakarta: UMY, ASPIKOM, Buku Litera.

McQuail, D. (2011). Teori Komunikasi Massa. Jakarta: Penerbit Salemba.

Mulyana, D. (2005). Ilmu Komunikasi Suatu Pengantar. Bandung : Remaja Rosdakarya.

Muslikhati, S. (2004). Feminisme dan Pemberdayaan Perempuan dalam Timbangan Islam. Jakarta: Gama Insani.

Qaimi, A. (2003). Single Parent: Peran Ganda Ibu dalam Mendidik Anak. Bogor: Cahaya.

Rahayu, A. S. (2017). Kehidupan Sosial Ekonomi Single Parent dalam Ranah Domestik dan Publik. Jurnal Analisisa Sosiologi, 6(1).

Ratna, N.K. (2010). Sastra dan Culture Studies. Yogyakarta: Pustaka Pelajar.

Sabatini, G. H. (2013). Representasi Stereotype Terhadap Suku Papua Korowai. KomuniTi. Vol. V, No. 3, Maret

Semovar, L. A., Porter, R. E., \& McDaniel, E.R. (2010). Komunikasi Lintas Budaya. Jakarta: Salemba Humanika.

Sihite, Romany. (2007). Perempuan, Kesetaraan, Keadilan. Jakarta: PT Rajagrafindo Persada.

Sukmono, F. G., \& Junaedi, F. (2014). Komunikasi Multikultur: Melihat Multikulturalisme dalam Genggaman Media. Yogyakarta: Buku Litera.

Supratman, Lucy.P. (2018). Family Communication On Single Mother Families. Jurnal ASPIKOM. Volume 3 No 4 , Januari

Utami, R.P., Boeriswati, E., Zuriyati, Z. (2018). Hegemoni Patriarki Publik Terhadap Tokoh Perempuan dalam Novel "Hanauzami” Karya Junichi Watanabe. Indonesia Language Education and Literature. Vol IV, No. 1, Desember

Wirawan,Sudarto. (2003). Peran Single Parent dalam Lingkungan Keluarga. Bandung: PT. Rosdakarya

Wood, J. T. (2009). Gendered lives: Communication, gender, and culture. Boston: Wadsworth Cengage Learning

Layliyah, Zahrotul. (2013). Perjuangan Hidup Single Parent. Journal Sosiologi Islam. Vol. 3, No. 1, April

Zaini, Nur. (2014). Representasi Feminisme Liberal dalam Sinetron; Analisis Semiotika Terhadap Sinetron Kita Nikah Yuk. Jurnal Penelitian Komunikasi dan Opini Publik Vol. 18 No. 3, Desember 